DOI: $10.2478 / \mathrm{v} 10025-010-0033-6$

JOURNAL OF WATER

AND LAND DEVELOPMENT

J. Water Land Dev. No. 13a, 2009: 263-272

\title{
Technical solutions for water damming structures in forest streams
}

\author{
Waldemar MIODUSZEWSKI
}

Institute for Land Reclamation and Grassland Farming, Department of Water Resources, Falenty, 05-090 Raszyn, e-mail: w.mioduszewski@imuz.edu.pl

\begin{abstract}
Small dams are basic elements of water retention systems in agricultural landscape and in forest ecosystems. Despite small water raising and location across small streams, these constructions should conform to security regulations and be resistant to destructive effect of flowing water. Moreover, they shouldn't be a strange element to the natural landscape of the river valley or forest ecosystem. Attention is also focussed in this paper on providing unobstructed flow in natural and artificial streams and on the possibility of migration for aquatic organisms. Examples of dams that do not hamper fish migration are given.
\end{abstract}

Key words: small retention, water raising constructions, forest ecosystems, water management, environmental protection

\section{INTRODUCTION}

It is commonly acknowledged that improving the structure of water balance in forests requires first of all limitation of the rapid outflow of spring waters and retention of water for dry periods. Structures raising the table of surface and ground waters are being built for this purpose. It is also assumed that such activities are environmental friendly and increase the biodiversity of river valleys and wetlands. Such assumption demands specific design and construction of technical elements of small retention. Structures should be harmonised with the natural surrounding (forest ecosystem, river valley) and shouldn't restrict animal, particularly fish, migration. On the other hand, technical facilities should provide appropriate exploitation and full security. Constructions should be resistant to destructive action of strong water current. Usually, natural materials like timber and stones are used to make hydraulic structures in forests or in naturally valuable areas. In such areas water raising is usually limited in order to not restrict fish migration. However, at high water raising and large flow it is necessary to reinforce the construction with concrete or steel elements which are often masked or covered with natural materials. 


\section{THE ROLE OF FOREST IN WATER CYCLING}

Forest ecosystems play an important role in the regulation of water cycling in a catchment basin (CIEPIELOWSKI and WŁODARCZYK, 2004; CHANG, 2005) All relationships that would enable quantitative assessment of the effect of forests on water balance structure are, however, not fully understood (BOJARSKI et al., 2005; CHANG, 2005). Many authors underline the need of further studies. Present knowledge allows for qualitative distinction of forest functions in hilly areas with compact impermeable soils from slightly other functions in lowland areas with sandy soils.

In areas devoid of forests with high slopes covered by impermeable soils (loams) water retention is very small and snow melt waters or heavy rainfalls flow rapidly on the ground surface. This results in high water flows and the risk of flood. Forested areas in such catchment basins markedly increase natural water retention through increasing hydraulic roughness of the ground (waters flow slower). Larger retention in the aeration zone (high permeability of forest soils, longer snow cover period) is observed in forested areas compared with agricultural catchments. Water flows slower on afforested slopes, its larger part is soaked up by soil and feeds groundwater aquifers. This in turn decreases high water flows in rivers.

A bit different situation is in lowland areas built mainly of permeable formations. In these areas under practically all conditions of land use (agriculture, barren lands) the whole rainfall and snow melt waters are soaked in the substratum. There is no surface runoff or it is very small. The surface runoff decisive for the intensity of flood flows takes place mainly from parts of catchment basin where the ground water table is situated near surface (the so-called hydrologically active areas) (SZYMCZAK, 2007). Forest ecosystems in a flat catchment basin of permeable soils affect flood waters less intensively since the ground water input to rivers is dominating there. Forest ecosystems situated on sandy formations largely affect, however, the intensity of ground water recharge. The input to aquifer layers might be limited due to high interception and evapotranspiration in forest ecosystems. Trees take up much more water than e.g. crop plants. Trees may also intercept up to $80 \%$ of rainfall annually while crop plants - no more than $10-20 \%$.

Natural retention capacity of forest catchment basins has been limited in many cases due to the construction of drainage systems. In forests situated on poorly permeable soils the construction of ditches, drainage and improper road constructions largely enhanced water outflow in surface runoff. In permeable areas ground waters subsided due to river regulations and to the drainage of adjacent wetlands, peatlands and small water bodies. In both cases the accelerated water outflow resulted in more frequent occurrence of droughts and floods (MIODUSZEWSKI, 2008).

It is commonly acknowledged that from the nature protection standpoint and for the restoration of forests' ability to control water cycling the actions (also technical) should be undertaken to reinstate potential retention capacities of forested 
catchment basins. In hilly areas one should aim at limiting surface runoff through preventing from erosion and by appropriate construction of roads and small water reservoirs in rivers.

Basic actions in lowland areas involve raising the ground water table in wetlands and river valleys. These measures improve water relations but also increase the retention capacity of mineral aquifers adjacent to wetland or river channel where the water table was elevated.

It appears that in every case hampering water outflow is possible through the construction of dams raising water permanently or periodically. This might involve small water reservoirs or only the elevation of water table within the channel of a river or draining ditch.

\section{ECOLOGICAL DETERMINANTS OF RAISING WATER IN STREAMS}

Construction of various dams across natural and artificial streams to elevate the surface and ground water table, to limit erosion and to retain water in reservoirs is anticipated in small retention programmes for forested areas, in plans of modernisation of draining systems and in wetland protection. The objects improve water balance and air-water relations in the valley with respect to the needs of forest ecosystems and environment. In most cases these are the dams of low water table rising localised in small streams. Noteworthy, such technical buildings need proper design and construction. A dam, even such of small water raising capacity, may pose a threat to man and natural environment during disastrous events. At wrong designed structures the escarps are being washed away which is dangerous for their stability. Excessive filtration under or near the dam is often observed. Such phenomena make the construction does not fulfil its function or is destroyed during high water flows. Even small buildings should be resistant to the destructive water action.

Water constructions should be composed into specific landscape of river valley, wetland or forest ecosystem. Usually, natural materials like timber or stones are being used in hydraulic structures built in forest ecosystems or in naturally valuable areas and the water rising is limited to not restrict fish migrations. However, at higher water raising and large water flows these constructions should be reinforced with concrete or steel elements. Such elements are often masked and covered by natural materials. Wooden structures are equally effective and composed into the landscape of forest ecosystem. This is particularly true for small dams (permanent barrages).

Depending on the river and the type and size of hydraulic structure man interferes in various ways with the so-called river continuum (Procesy..., 1995). Even small dam causes a rapid change in the water level which might appear a barrier for aquatic fauna. Risks associated with barriers in river channels pertain mainly to 
ichthyofauna since the survival of many fish species depends on the possibility of their movement upstream.

Fish are able to overcome water current and barriers. Salmonids and trouts were observed to overcome the waterfalls 0.8 to $1.7 \mathrm{~m}$ high (WIŚNIOWOLSKI, 2002). These are, however, exceptional abilities. Usually, fish abilities are more modest. It is assumed that the threshold water velocities and respective waterfalls (differences in up and down water table) are as follows (WIŚNIOWOLSKI, 2002):

- for the trout and salmonids

- for rheophilic dwarf fish

$$
\begin{array}{ll}
\text { - for the trout and salmonids } & v=2.0 \mathrm{~m} \cdot \mathrm{s}^{-1} ; \Delta h=0.20 \mathrm{~m}, \\
\text { - for rheophilic dwarf fish } & v=1.5 \mathrm{~m} \cdot \mathrm{s}^{-1} ; \Delta h=0.11 \mathrm{~m}, \\
\text { - for other species and juvenile forms } & v=1.0 \mathrm{~m} \cdot \mathrm{s}^{-1} ; \Delta h=0.05 \mathrm{~m} .
\end{array}
$$

Maintaining river continuum to facilitate free movement for fish needs special solutions in designing the dams.

Structures constructed in even small streams may negatively affect aquatic fauna. Therefore, dams raising higher the water table for the benefit of natural river values should be equipped with fish ladders (ŁOŚ and ŻBIKOWSKI, 1989; WIŚNIOWOLSKI, 2002). There are fish ladders of various designs (Fish passes..., 2002; LUBIENIECKI, 2002). Now preferred ladders resemble natural stream. They are usually the structures made of stones in a form of typical rapids of increased roughness.

Most structures for small water retention in forests are made as the fixed barrage (CIEPIELOWSKI and WŁODARCZYK, 2004) with no possibility of controlling water level. If the dams exceed $0.2-0.4 \mathrm{~m}$ in height they become barriers for fish (ŁOŚ and ŻBIKOWSKI, 1989; LUBIENIECKI, 2002; WIŚNIOWOLSKI, 2002). It is necessary to adjust dam constructions to the requirements of environmental protection. At smaller waterfalls (beneath $1.0 \mathrm{~m}$ ) dams may be made in a form of cascade (without fish ladder) which would not hamper fish movement.

\section{RAPIDS AND DAMS}

Most favourable solutions that enable free fish movement are specifically formed rapids as those presented in Figure 1. Typical rapids, even such made of stones (Fig. 1a), might be barriers for fish due to high water velocity. At higher waterfalls and longer rapids even salmonids are not able to overcome this barrier (WIŚNIOWOLSKI, 2002). In rapids with increased roughness (Fig. 1b) water velocity is lower. If stones are arranged to form small pools (Fig. 1c) then the rapid's length and water elevation are not a problem for fish.

Dams are often made of gabions. They permit to adjust the dam to the type of substratum and construct dams of various shapes. Fig. 2 presents an example of the dam that allows for free fish movement. Gabions can be arranged in a way to produce cascade of small pools. The structure may be made of only gabions (Fig. 2) or in combination with wooden tight walls (Fig. 3). Similar effect may be obtained by 
a)

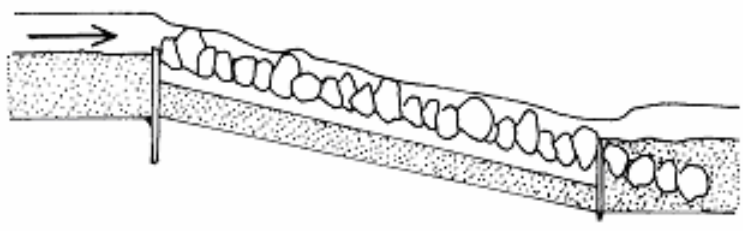

b)

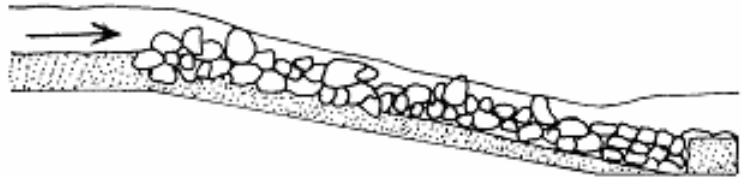

c)

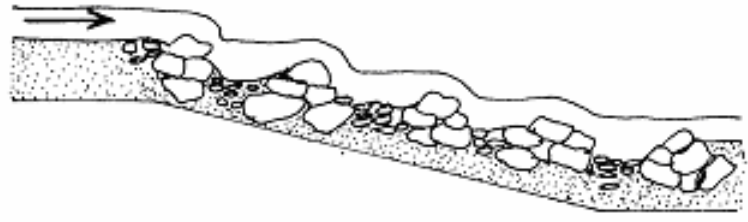

Fig. 1. Examples of rapids: a) typical rapid, b) rapid with increased roughness, c) rapid with pools (Fish passes..., 2002)

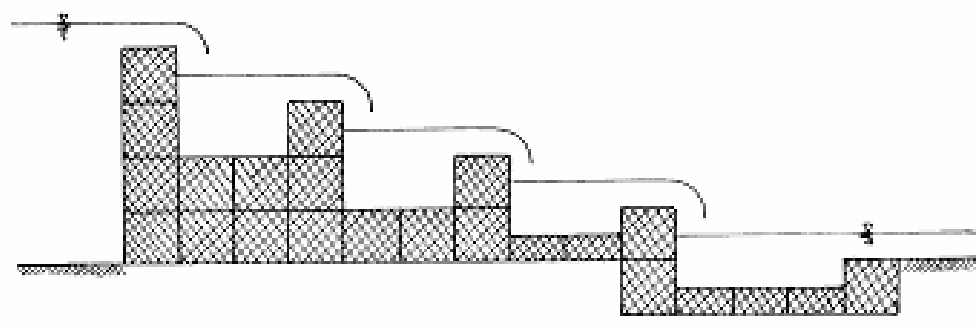

Fig. 2. Massive dam made of gabions

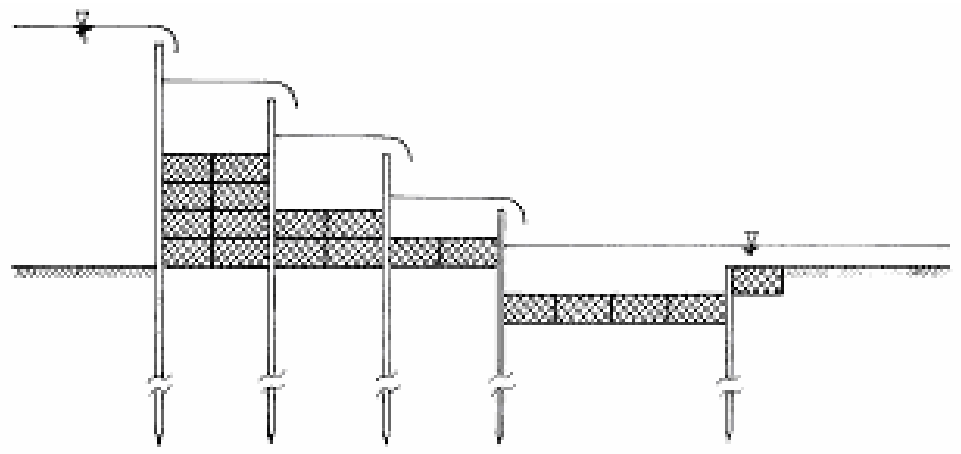

Fig. 3. Example of a dam made of gabions and tight walls 
using instead of gabions the bags of jute or textile filled to $3 / 4$ with sand (Fig. 4). More durable structure may be obtained when the bags are filled with a mixture of sand and cement setting under water. Stones may be placed between tight walls instead of bags. It is also possible to cover the bags with a layer (minimum 10-15 $\mathrm{cm}$ thick) of stones. Such structures are easily built. Works can be done in the stream's canal without the need of digging the release canal. Moreover, such hydraulic structures are durable, stable and can easily be incorporated in the river valley landscape (MIODUSZEWSKI, 2006).

a)

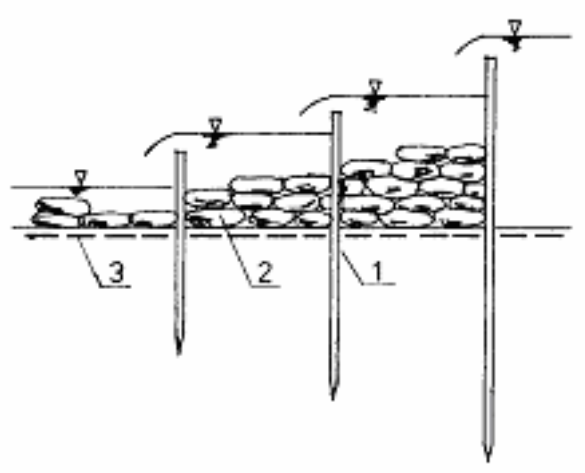

b)

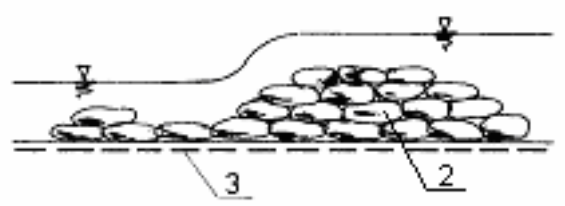

Fig. 4. Examples of the use of bags in the construction of water raising barrages; 1 - tight wall, 2 - bags, 3 - geotextile

At higher water velocities and water elevations the environmental friendly dam can be made of concrete or concrete prefabricates in a form of cascade of small pools. To incorporate such structures into surrounding landscape concrete may be covered by stones (Fig. 5). Such constructions are used in the regulation of mountain brooks (BOJARSKI et al., 2005). An example of one of the possible environmental friendly solutions is shown in Fig. 5.

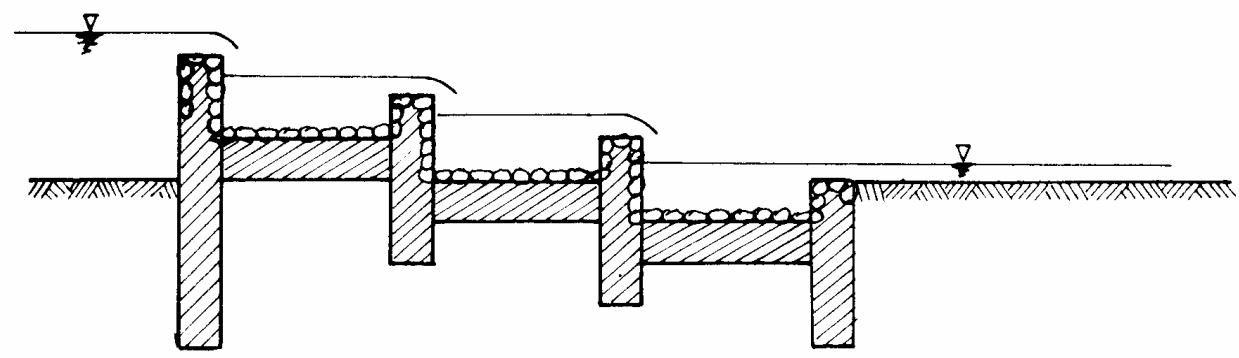

Fig. 5. A scheme of concrete stone paved dam 
The use of timber is recommended in constructing dams in forest areas. They interfere least with the natural forest ecosystem. There are many examples of simple wooden constructions in the literature. One should, however, remember that even the best preserved timber is subject to rotting. Remounts and current repairs are thus necessary.

\section{MODERNISATION OF STRUCTURES}

Many dams, including those in forested areas, were made without fish ladders or other devices facilitating free fish migration upstream. Many actions are now undertaken to make streams passable - mainly by the construction of fish ladder. Sometimes, simple reconstruction of a dam is possible to enable fish migration. An example of adaptation of the typical weir to natural requirements is given in Fig. 6 . Filling the concrete barrage with stones and appropriate arrangement of large blocks makes a ramp which is not a barrier for migrating aquatic fauna and still plays its hydraulic role.

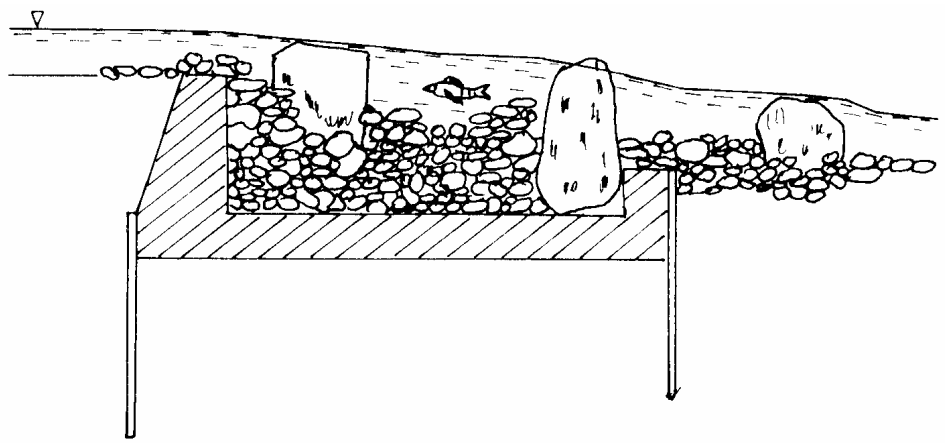

Fig. 6. Reconstruction of a barrage to enable fish movement (Fish passes..., 2002)

Rapids of high slopes where water velocity is higher than $1 \mathrm{~m} \cdot \mathrm{s}^{-1}$ are also hard to overcome by fish, particularly when the bottom is smooth. Example shown in Fig. 7 indicates a possibility of reconstruction of such rapid into a ramp of mild slope and composed of a cascade of small pools (Fish passes..., 2002).

Various methods may be used to adapt a structure to environmental requirements (restoration of river continuum, liquidation of artificial barriers) depending on the construction, technical status and aims of the existing structure. It is also important to adopt it to surrounding river valley landscape. Most existing hydrologic structures are the concrete boxes which often spoil the landscape. This aspect should also be considered in the reconstruction and modernisation of structures and water facilities. 

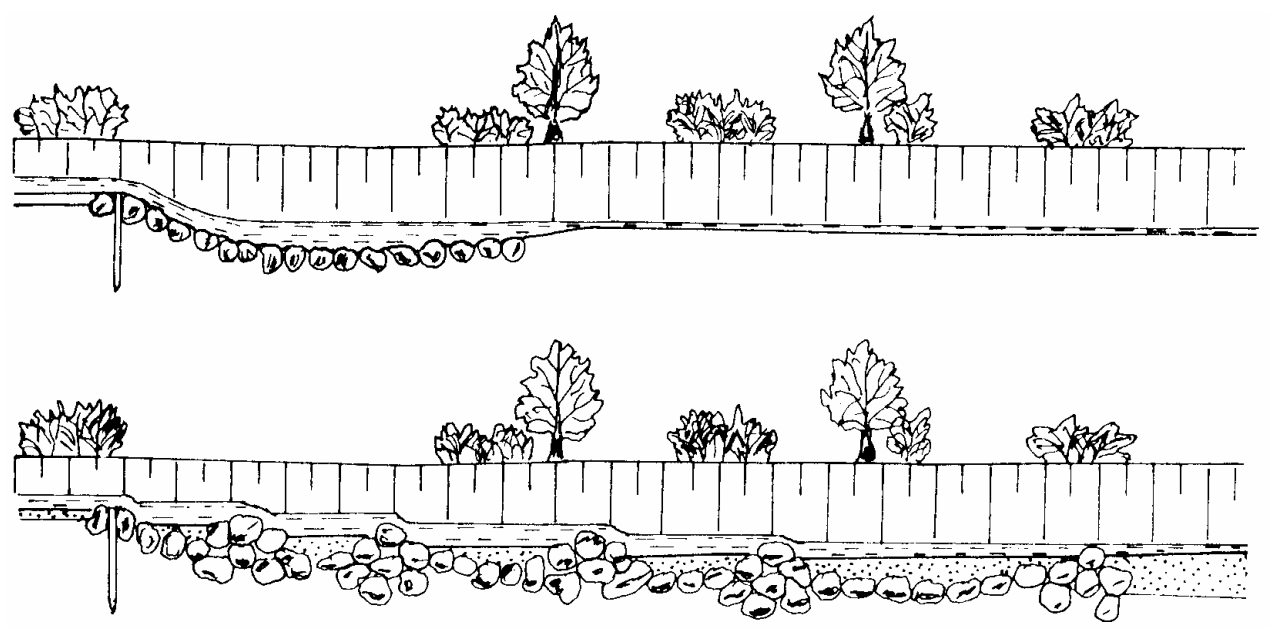

Fig. 7. An example of the reconstruction of stone rapids (Fish passes..., 2002)

\section{SUMMARY}

Water Framework Directive of the EU requires bringing the rivers to good ecological status. Hence, the need to maintain or restore passable river channels to enable migrations of aquatic fauna. On the other hand, it is often necessary to dam the river channel for economic, natural or hydrologic reasons. Technical facilities used in the programme of small water retention in forests have to ensure nature protection in both natural and artificial streams. The use of special constructions allows for effective rising of the water table and enables free fish movement upstream. Various materials may be used in such constructions including concrete structures or bags filled with sand or sand and cement. Structures made of natural stones are very effective from the hydraulic and biological point of view. They form numerous fissures and variable flow conditions - there are places of faster and slower water current and areas where fish may rest.

\section{REFERENCES}

1. Bojarski A., JeleńSKi J., Jelonek M., LitewKa T., Wyżga B., ZalewSKi J., 2005. Zasady dobrej praktyki w utrzymaniu rzek i potoków górskich. (Principles of good practice in maintaining rivers and mountain streams) Warszawa, Min. Środ.

2. Chang M., 2005. Forest hydrology. An introduction to water and forest. New York, Wydaw. Taylor $\&$ Francis.

3. Ciepielowski A., WŁodarczyk A., 2004. Budowle wodne na obszarach chronionych. (Water constructions in protected areas). Acta Sci. Polon. - Architekt., 3(1).

4. Fish passes - design, dimensions and monitoring, 2002. Rome, FAO. 
5. JĘDRYKA E., 2006. Proekologiczne budowle wodne. Poradnik. (Environmental friendly water constructions). Falenty, Wydaw. IMUZ.

6. LuBIENIECKI B., 2002. Przepławki i drożność rzek. (Fish ladders and the passableness of rivers). Olsztyn, IRS.

7. Łoś M.J., ŻBIKOwSKI A., 1989. Rozwiązania techniczne i środki stosowane dla ochrony środowiska w rejonie zbiorników wodnych. (Technical solutions and means used in environmental protection near water reservoirs). Melior. Rol., 2.

8. MiodusZewSKi W., 2006. Małe zbiorniki wodne. (Small water reservoirs). Falenty, Wydaw. IMUZ.

9. MiodusZEWSKI W., 2008. Mała retencja w lasach elementem kształtowania i ochrony zasobów wodnych. (Small water retention in forests as an element of management and protection of water resources). St. Mater. CEPL, 18.

10. Procesy biologiczne w ochronie i rekultywacji nizinnych zbiorników zaporowych, (Biological processes in the protection and restoration of lowland dam reservoirs), 1995. Pr. zbior. Red. A. Zalewski. Bibl. Monitor. Środ. Łódź, PIOŚ.

11. Przyjazne naturze kształtowanie rzek i potoków - praktyczny poradnik, (Nature friendly management of rivers and brooks - practical guide), 2006. Red. M. Zalewski. Kraków, Wydaw. Polska Zielona Sieć.

12. SZYMCZAK T., 2007. Wyznaczanie obszarów szczególnie podatnych na występowanie odpływu bezpośredniego i spływu zanieczyszczeń obszarowych na przykładzie małej zlewni rolniczej w dorzeczu Liwca. (Estimating areas particularly susceptible to direct outflow and surface runoff - an example of small agricultural watershed in the Liwiec River catchment basin). Mater. Konf. Zagospodarowanie zlewni Bugu i Narwi w ramach zrównoważonego rozwoju. Warszawa, Monogr. WSEiZ.

13. WIŚNIOWOLSKI W., 2002. Zmiany w składzie ichtiofauny, jej biomasa oraz odłowy w wybranych zbiornikach zaporowych Polski. (Changes in the composition of ichthyofauna, its biomass and catches in selected dam reservoirs in Poland). Arch. Pol. Fish., 2 suppl. 2.

14. ŻBIKOWSKI A. ŻELAZO J., 1993. Ochrona środowiska w budownictwie wodnym. (Environmental protection in water engineering). Mater. Inf. Warszawa: MOŚZNiL.

15. ŻELAZO J., PoPeK Z., 2002. Podstawy renaturyzacji rzek. (Principles of river restoration). Warszawa, Wydaw. SGGW.

\section{STRESZCZENIE}

\section{Techniczne rozwiązania budowli piętrzących w ciekach na obszarach leśnych}

Słowa kluczowe: budowle piętrzqce, ekosystemy leśne, gospodarka wodna, mała retencja, ochrona środowiska

Podstawowym technicznym elementem systemu retencjonowania wód w krajobrazie rolniczym oraz w ekosystemach leśnych są małe budowle piętrzące. Charakteryzują się one prostą konstrukcją. Pomimo zazwyczaj niewielkich piętrzeń oraz lokalizacji tych budowli na małych ciekach, powinny one spełniać wymagania w zakresie bezpieczeństwa konstrukcji i być odporne na destrukcyjne działanie płynącej wody. Ponadto nie powinny stanowić obcego elementu w naturalnym krajobrazie doliny rzecznej i ekosystemie leśnym. W pracy zwraca się również uwagę na zapewnienie drożności naturalnych i sztucznych cieków dla umożliwienia przemieszczania się organizmów wodnych. Wynika to m.in. z postanowień Ramo- 
wej Dyrektywy Wodnej Unii Europejskiej, która wymaga doprowadzenia rzek do dobrego stanu ekologicznego, w tym zachowania lub odtworzenia drożności koryt rzecznych celem umożliwienia przemieszczania się fauny wodnej. Zastosowanie specjalnych konstrukcji budowli pozwala na efektywne podpiętrzenie wody, a jednocześnie umożliwia swobodne przemieszczanie się ryb w górę rzeki. Dla celów budowy stosowane mogą być różne materiały, łącznie $\mathrm{z}$ budowlami betonowymi lub wykonanymi z worków wypełnionych piaskiem lub piaskiem z cementem. Konstrukcje budowli, w których wykorzystuje się naturalne kamienie, są bardzo efektywne hydraulicznie i biologicznie. Tworzą one bowiem liczne szczeliny i zróżnicowane warunki przepływu - występują miejsca o silniejszym i słabszym nurcie wody oraz obszary, na których ryby mogą odpocząć. W pracy podano przykładowe konstrukcje budowli piętrzących przyjaznych środowisku, które nie stanowią przeszkody w migracji ryb.

Received 15.01.2009

Reviewers:

Assist. prof. Magdalena Borys

Prof. Edward Pierzgalski 